\title{
HUBUNGAN ANTARA KEBIASAAN MEROKOK DAN TIMBULNYA CARIES DENTIS PADA SISWA SMK MUHAMMADIYAH 1 KOTA MALANG
}

\author{
Reza Adityawan Prakoso', Nanang Mardiraharjo ${ }^{2}$, Sari Yunita Sukmawati Noer ${ }^{3}$ \\ Fakultas Kedokteran Universitas Muhammadiyah Malang, Jl. Bendungan Sutami 188 A Kota Malang, \\ 65145, Indonesia, (0341) 582060
}

\begin{abstract}
ABSTRAK
Hubungan Antara Kebiasaan Merokok dan Timbulnya Caries Dentis Pada Siswa SMK Muhammadiyah 1 Kota Malang. Latar Belakang: Caries merupakan suatu penyakit pada gigi kebiasaan merokok. Nicotine pada rokok mengakibatkan penghambatan ganglion sehingga sekresi saliva yang merupakan faktor protektif bagi gigi akan terhambat. Selain itu merokok juga mengganggu mikrosirkulasi gigi dan mulut sehingga jaringan gingiva yang divaskularisasi oleh pembuluh darah akan kekurangan oxygen dan bahan nutrisi yang diperlukan. Tujuan: Untuk membuktikan adanya hubungan antara kebiasaan merokok dan timbulnya caries dentis Metode: Analytical observation dengan pendekatan crosssectional. Sampel yang digunakan adalah siswa perokok dan non perokok yang kemudian dilakukan pemeriksaan caries, analisis data dengan menggunakan uji korelasi Rank Spearman. Hasil Penelitian: 126 responden dimana laki-laki sebanyak 108 responden $(85,7 \%)$ dan perempuan sebanyak 18 responden (14,3\%). Frekuensi konsumsi rokok paling banyak adalah 5-14 batang sebanyak 24 responden (19,0\%) dimana 22 berstatus caries dan 2 responden lainnya berstatus non caries dengan DMF-T 66 dan $>15$ batang sebanyak 24 responden (19,0\%) dimana 19 responden berstatus caries dan 5 lainnya berstatus non caries dengan DMF-T 105 sedangkan yang mengkonsumsi rokok 1-4 batang per hari sebanyak 18 responden (14,3\%) dimana 8 responden berstatus caries dan 10 responden lainnya berstatus non caries dengan DMF-T 17. Adapun 60 responden $(47,6 \%)$ lainnya merupakan non perokok dimana 38 responden berstatus caries dan 22 responden lainnya berstatus non caries dengan DMF-T 140. Hasil uji korelasi Rank Spearman menunjukkan nilai koefisien 0,266 dan nilai signifikansi 0,000 dengan nilai $\alpha 0.01(\mathrm{p}<\alpha)$. Kesimpulan: Terdapat hubungan antara kebiasaan merokok dan timbulnya caries dentis.
\end{abstract}

Kata Kunci: Merokok, caries dentis.

\begin{abstract}
Correlation Between Smoking Habbit And The Incidence of Caries Dentis On The Students of SMK Muhammadiyah 1 Malang City. Backgrounds: Caries is a disease of the teeth caused by smoking. Nicotine in cigarettes resulted in the ganglion inbibition so the secretion of saliva which is a protective factor for tooth will be hampered. In addition smoking is also disturbing microcirculation of teeth and mouth so the gingival tissue which is vascularised by the blood vessels will lack the oxygen and nutrients needed. Objective: To prove the relation between smoking and the incidence of caries dentis. Method: Analytical observation with cross-sectional approach. The samples used were student smokers and non smokers who follow the caries checkup, data analysis using the Spearman rank correlation test. Research Results: From the research results have been obtained 126 respondents which 180 respondents are male (85.7\%) and 18 respondents are female (14.3\%). Frequency of 5-14 bars cigarette consumption is 24 respondents (19.0\%) which 22 respondents belong to caries and two respondents are non-caries with DMF-T 66 and $>15$ cigarettes are 24 respondents (19.0\%) which 19 respondents belong to caries and 5 respondents are non-caries with DMF-T 105, while they are who taking smoking 1-4 cigarettes per day are 18 respondents (14.3\%) which 8 respondents are caries and 10 respondents are non caries with DMF-T 17. The 60 respondents (47.6\%) are non-smokers which 38 respondents are caries and 22 respondents belong to non-caries with DMF-T 140. Spearman rank correlation test results show the value of the coefficient is 0.266 and the significance value is 0.000 with $\alpha$ value $0.01(p<\alpha)$. Conclusion: There is correlation between smoking habbit and the incidence of caries dentis.
\end{abstract}

Key words: Smoking, Caries Dentis

\section{PENDAHULUAN}

Ketergantungan terhadap rokok sudah menjadi epidemi secara global yang dapat menyebabkan kecacatan, penyakit, produktivitas menurun, dan kematian. Namun demikian, kesadaran untuk berhenti mengkomsumsi rokok sangat sulit dilakukan, karena banyak faktor yang mempengaruhinya (Gondodiputro, 2007). Di Indonesia, sebesar 5\% penduduk berumur 15 tahun ke atas merokok (tiap hari dan kadang-kadang). Persentase merokok pada 
laki-laki konstan tinggi yaitu 63\% pada tahun 2001, 2003, dan 2004; pada perempuan jauh lebih rendah namun ada peningkatan dari 1,4\% pada tahun 2001 menjadi 1,7\% pada tahun 2003 dan 4,5\% pada tahun 2004. Persentase merokok di pedesaan (37\%) lebih tinggi dibandig di perkotaan (32\%). Persentase merokok terendah pada kelompok strata ekonomi terendah (30\%), sedangkan pada kelompok strata ekonomi yang lebih tinggi berkisar antara 36-37\% (Depkes RI, 2007).

Gaya hidup yang terlihat sebagai kebiasaan dan banyaknya merokok juga dapat memperburuk kesehatan periodontium. Merokok akan merusak mikrosirkulas dalam gingiva sehingga secara kronis bagian dari jaringan gingiva yang divaskularisasi oleh kapiler-kapiler akan kekurangan oxygen dan bahan-bahan nutrisi yang diperlukan (Nurul, 2010). Berbagai macam rokok dan intensitas kebiassaan merokok telah terbukti mempunyai hubungan kuat dengan status jaringan gingiva, kerusakan jaringan periodontium, serta keadaan berat periodontitis. Perokok mempunyai risiko menderita periodontitis atau kerusakan jaringan periodontium sebanyak 2-7 kali lebih besar daripada bukan perokok (Nurul, 2010). Salah satu gangguan periodontium akibat merokok adalah caries dentis. Pada manusia modern yang hidup dalam masyarakat industri yang sudah maju, caries merupakan hal yang sudah biasa, tetapi frekuensi caries berbeda di tiap negeri dan di antara individu itu sendiri (Kidd.and Joyston, 1992).

Caries pada umumnya dapat dicegah, akan tetapi pencegahan banyak bergantung pada pasien, karena banyak upaya pencegahan memerlukan kerjasama pasien yang aktif. Contohnya, menghindari kudapan manis, penggunaan fluoride di rumah, pengendalian plak yang efektif, semuanya membutuhkan kerja sama pasien yang baik (Kidd and Joyston, 1992). Dari survei awal yang dilakukan oleh peneliti di SMK Muhammadiyah 1 Kota Malang, sebagian besar siswa SMK Muhammadiyah 1 Kota Malang merupakan perokok aktif. Menurut beberapa siswa yang diwawancarai oleh peneliti, hal ini terutama berhubungan dengan pergaulan antar teman, sehingga sebagian besar siswa SMK Muhammadiyah 1 Kota Malang mempunyai potensi untuk mengalami caries dentis. Berdasarkan penjelasan diatas, penulis ingin mengetahui hubungan antara merokok dengan terjadinya caries dentis pada siswa di SMK Muhammadiyah 1 Kota Malang.

\section{METODE DAN BAHAN}

Penelitian ini merupakan penelitian yang bersifat analytical observation, dengan menggunakan pendekatan cross sectional. Penelitian ini dilakukan di SMK Muhammadiyah 1 Kota Malang. Populasi dalam penelitian ini adalah seluruh siswa di SMK Muhammadiyah 1 Kota Malang. Sampel dalam penelitian ini adalah 126 siswa SMK Muhammadiyah 1 Kota Malang yang memenuhi kriteria inklusi dan eksklusi.

Penelitian ini menggunakan total sampling yang diambil dari seluruh SMK Muhammadiyah 1 Kota Malang yang memenuhi kriteria sampel. Kriteria inklusi dalam penelitian ini adalah Siswa SMK Muhammadiyah 1Kota Malang. Kriteria eksklusi adalahSiswa SMK Muhammadiyah 1 Kota Malang yang menderita gingivitis, Siswa SMK Muhammadiyah 1 Kota Malang yang tidak hadir dan atau tidak bersedia dalam penelitian ini.
Variabel bebas dalam penelitian ini adalah kebiasaan merokok. Variabel tergantung dalam penelitian ini adalah caries dentis.

Kebiasaan merokok adalah aktivitas yang dilakukan oleh siswa SMK Muhammadiyah 1 Kota Malang dalam menghisap rokok yang menyala dengan kriteria sebagai berikut perokok ringan (1-4 batang rokok batang per hari) perokok sedang (menghisap 5-14 batang rokok batang per hari )perokok berat (menghisap $>15$ batang rokok batang per hari) Caries merupakan suatu lubang pada gigi baik pada satu gigi atau lebih yang diketahui dengan inspeksi untuk lubang yang besar dan dengan menggunakan sonde untuk lubang yang kecil. Alat dan Bahan Penelitian Handscoonm, penlight,kaca mulut, sonde gigi, Lembar pemeriksaan.

\section{HASIL DAN PEMBAHASAN}

Berdasarkan penelitian yang dilakukan terhadap siswa SMK Muhammadiyah 1 Kota Malang pada bulan Januari 2012 diperoleh 126 sampel penelitian berdasarkan kriteria inklusi dan eksklusi yang telah ditetapkan oleh peneliti. Data primer mengenai keadaan gigi tiap siswa, diperoleh dengan melakukan pemeriksaan caries oleh tim peneliti. Sedangkan data mengenai kebiasaan merokok tiap siswa, diperoleh dengan bantuan kuesioner.

Dari 126 sampel tercatat responden paling muda berusia 14 tahun dan responden paling tua berusia 20 tahun dengan rincian yang dapat dilihat pada tabel berikut:

\begin{tabular}{lll}
\hline Usia & Frekuensi & Persentase $(\%)$ \\
\hline 14 tahun & 3 & 2,4 \\
15 tahun & 23 & 18,2 \\
16 tahun & 35 & 27,8 \\
17 tahun & 32 & 25,4 \\
18 tahun & 19 & 15,1 \\
19 tahun & 13 & 10,3 \\
20 tahun & 1 & 0,8 \\
\hline Total & 126 & 100
\end{tabular}

Berdasarkan tabel tersebut dari 126 sampel didapatkan bahwa sebagian besar usia responden adalah usia 15-17 tahun sebanyak 90 responden $(71,4 \%)$, dan sisanya yang berusia 18-20 tahun sebanyak 33 responden $(26,2 \%)$, serta usia 14 tahun sebanyak 3 orang (2,4\%).

Dari 126 sampel tercatat responden laki-laki sebesar 108 responden dan responden perempuan sebesar 18 responden dari 126 sampel tercatat 66 responden laki-laki merupakan perokok aktif:

\begin{tabular}{lccccc}
\hline \multicolumn{1}{c}{ Jenis } & \multicolumn{2}{c}{ Frekuensi Perokok } & Frekuensi & $\begin{array}{c}\text { Persentase } \\
\text { Perokok }(\%)\end{array}$ & $\begin{array}{c}\text { Persentase Non } \\
\text { Kerokok }(\%)\end{array}$ \\
\cline { 2 - 3 } \multicolumn{1}{c}{$(+)$} & $(-)$ & & 108 & 61,1 & 38,9 \\
Laki-laki & 66 & 42 & 108 & 0 & 100 \\
Perempuan & 0 & 18 & 18 & 0 & 47,6 \\
\hline Total & 66 & 60 & 126 & 52,4 & \\
\hline
\end{tabular}

Berdasarkan tabel 126 sampel, diketahui frekuensi perokok pada laki-laki sebanyak 66 responden $(61,1 \%)$ dari 108 responden laki- laki, dan frekuensi non perokok sebanyak 42 responden (38,9\%) dari 108 responden lakilaki. Sedangkan frekuensi perokok pada perempuan sebanyak 0 responden $(0 \%)$ dari 18 responden perempuan, dan 
frekuensi non perokok sebanyak 18 responden (100\%) dari 18 responden perempuan.

Frekuensi Jenis Kelamin dan Timbulnya Caries Dentis dari 126 sampel tercatat 74 responden laki-laki dari 108 responden laki-laki mengalami caries dentis dan 13 responden dari 18 responden perempuan mengalami caries dentis dengan rincian yang dapat dilihat

\begin{tabular}{lccccc}
\hline \multicolumn{1}{c}{ Jenis } & \multicolumn{2}{c}{ Frekuensi Caries } & Frekuensi & $\begin{array}{c}\text { Persentase } \\
\text { Karies }(\%)\end{array}$ & $\begin{array}{c}\text { Persentase Non } \\
\text { Caries }(\%)\end{array}$ \\
\cline { 2 - 3 } \multicolumn{1}{c}{$(+)$} & $(-)$ & & 68,5 & 31,5 \\
Laki-laki & 74 & 34 & 108 & 72,2 & 27,8 \\
Perempuan & 13 & 5 & 18 & 69 & 31 \\
\hline Total & 87 & 39 & 126 & 69 \\
\hline
\end{tabular}

Berdasarkan tabel tersebut diketahui frekuensi caries dentis pada laki-laki sebanyak 74 responden (68,5\%) dari 108 responden laki-laki, dan frekuensi non caries dentis sebanyak 34 responden $(31,5 \%)$ dari 108 responden laki-laki. Sedangkan frekuensi caries denitis pada perempuan sebanyak 13 responden $(72,2 \%)$ dari 18 responden perempuan, dan frekuensi non caries denitis sebanyak 5 responden $(27,8 \%)$ dari 18 responden perempuan.

Dari hasil penyebaran kuesioner yang dilakukan oleh peneliti, dapat diketahui merk rokok yang dikonsumsi adalah Sampoerna Mild, L.A., Marlboro, dan Gudang Garam Internasional sebanyak 40 responden $(60,6 \%)$. Sedangkan sisanya adalah Dunhill, Gudang Garam Surya, Gudang Garam Surya Profesinal Mild, Geo Mild, Score Mild, Sejati, Djarum Black Menthol, U Mild, Ares, dan Cigarillos Cerutu sebanyak 26 responden $(39,4 \%)$.

Dari hasil penyebaran kuesioner yang dilakukan oleh peneliti, dapat diketahui lamanya sampel merokok yang dapat dilihat :

\begin{tabular}{lcc}
\hline \multicolumn{1}{c}{ Lama Merokok } & Frekuensi & Persentase $(\%)$ \\
\hline$<1$ tahun & 34 & 51,5 \\
$<2$ tahun & 8 & 12,1 \\
$>3$ tahun & 24 & 36,4 \\
Total & 66 & 100
\end{tabular}

Berdasarkan tabel 5.6 dari 66 responden laki-laki perokok, diketahui frekuensi lama merokok $<1$ tahun sebanyak 34 responden (51,5\%), frekuensi lama merokok $<2$ tahun sebanyak 8 respoden (12,1\%), dan frekuensi lama merokok $>3$ tahun sebanyak 24 responden $(36,4 \%)$.

Dari hasil penyebaran kuesioner yang dilakukan oleh peneliti, dapat diketahui lamanya sampel merokok yang dapat dilihat :

\begin{tabular}{|c|c|c|c|c|c|}
\hline \multirow{2}{*}{$\begin{array}{c}\text { Jumlah } \\
\text { Rokok Per } \\
\text { Hari }\end{array}$} & \multicolumn{4}{|c|}{$\begin{array}{l}\text { Frekuensi caries } \\
\end{array}$} & \multirow[b]{2}{*}{ DMF-T } \\
\hline & $(-)$ & $(+)$ & $\mathrm{F}$ & $(\%)$ & \\
\hline 0 batang & 22 & 38 & 60 & 47,6 & 140 \\
\hline 1-4 batang & 10 & 8 & 18 & 14,3 & 17 \\
\hline 5-14 batang & 5 & 19 & 24 & 19,0 & 66 \\
\hline$>15$ batang & 2 & 22 & 24 & 19,0 & 105 \\
\hline Total & 39 & 87 & 126 & 100 & 328 \\
\hline
\end{tabular}

Berdasarkan tabel dari 66 responden laki-laki perokok, diketahui frekuensi lama merokok $<1$ tahun sebanyak 34 responden $(51,5 \%)$, frekuensi lama merokok $<2$ tahun sebanyak 8 respoden $(12,1 \%)$, dan frekuensi lama merokok $>3$ tahun sebanyak 24 responden $(36,4 \%)$.
Berdasarkan data 66 responden laki-laki perokok, diketahui frekuensi alasan merokok karena ikut-ikutan teman sebanyak 19 responden (28,8\%), frekuensi alasan merokok karena gengsi sebanyak 15 responden $(22,7 \%)$, dan frekuensi alasan merokok karena coba-coba sebanyak 32 responden (48,5\%).

Berdasarkan tabel 5.10 dari 126 sampel, diketahui frekuensi responden menggosok gigi 2 x sehari sebanyak 75 responden $(59,5 \%)$ dimana 73 responden berstatus caries, frekuensi responden menggosok gigi 3 x sehari sebanyak 43 responden $(34,1 \%)$ dimana 6 responden berstatus caries, dan frekuensi responden tidak rutin menggosok gigi sebanyak 8 responden $(6,4 \%)$ dimana 8 responden berstatus caries.

Hubungan Antara Kebiasaan Merokok dan Timbulnya Caries Dentis dari 126 sampel tercatat 49 responden dari 66 responden perokok aktif mengalami caries dentis dengan rincian yang dapat dilihat 66 responden laki-laki perokok, diketahui frekuensi konsumsi rokok paling banyak adalah 514 batang sebanyak 24 responden $(19,0 \%)$ dengan DMF-T 66 dan $>15$ sebanyak 24 responden $(19,0 \%)$.

Untuk mengetahui adanya hubungan antara kebiasaan merokok dan untuk mengetahui adanya hubungan antara kebiasaan merokok dan timbulnya caries dentis pada siswa SMK Muhammadiyah 1 Kota Malang, maka perlu dibentuk tabulasi silang (crosstabs) yang dapat menggambarkan penyebaran data secara lebih terinci. Perokok dimana tidak mengalami caries dentis sebanyak 22 orang responden (17,5\%) dan 38 orang responden $(30,2 \%)$ mengalami caries dentis. 18 orang responden yang merupakan perokok ringan dimana tidak mengalami caries dentis sebanyak 10 orang $(7,9 \%)$ dan 8 orang $(6,3 \%)$ mengalami caries dentis. Dari 24 orang siswa yang merupakan perokok sedang dimana tidak mengalami caries dentis sebanyak 5 orang $(4,0 \%)$ dan 19 orang (15,1\%) mengalami caries dentis. Dari 24 orang siswa yang merupakan perokok berat dimana tidak mengalami caries dentis sebanyak 2 orang $(1,6 \%)$ dan 22 orang $(17,5 \%)$ mengalami caries dentis.

Pada penelitian ini menggunakan uji korelasi Rank Spearman untuk mengetahui adanya hubungan antara kebiasaan merokok dan timbulnya caries dentis pada siswa SMK Muhammadiyah 1 Kota Malang didapatkan nilai koefisien korelasi Rank Spearman sebesar 0.266, dengan nilai signifikansi (p) sebesar 0.003 yang lebih kecil dari alpha 0.05 , sehingga Ho ditolak, dan dapat disimpulkan bahwa terdapat hubungan antara kebiasaan merokok dan timbulnya caries dentis pada siswa SMK Muhammadiyah 1 Kota Malang. Dari hasil pengujian menunjukkan korelasi yang positif $(\mathrm{rs}=0,266)$, artinya semakin tinggi tingkat kebiasaan merokok pada siswa SMK Muhammadiyah 1 Kota Malang, akan meningkatkan risiko terjadinya caries dentis. Adanya kaitan antara tingkat kebiasaan merokok dan timbulnya caries dentis pada siswa SMK Muhammadiyah 1 Kota Malang

Penelitian ini dilakukan untuk mengetahui adanya hubungan antara kebiasaan merokok dan terjadinya caries dentis pada siswa SMK Muhammadiyah 1 Kota Malang. Sampel terdiri dari 126 orang siswa SMK Muhammadiyah 1 Kota Malang yang memenuhi kriteria inklusi da eksklusi. 
Berdasarkan hasil penelitian mengenai kebiasaan merokok, didapatkan frekuensi konsumsi rokok paling banyak adalah 5-14 batang 24 responden (19,0\%) dengan DMF-T 66 dan $>15$ sebanyak 24 responden (19,0\%) dengan DMF-T 105 sedangkan yang mengkonsumsi rokok 1-4 batang per hari sebanyak 18 responden (14,3\%) dengan DMF-T 17. Adapun 60 responden $(47,6 \%)$ lainnya merupakan non perokok dengan DMF-T 140.

Gaya hidup yang terlihat sebagai kebiasaan dan banyaknya merokok dapat memperburuk kesehatan periodontium. Merokok akan merusak mikrosirkulasi dalam gingiva sehingga secara kronis bagian dari jaringan gingiva yang divaskularisasi oleh kapiler-kapiler akan kekurangan oxygen dan bahan-bahan nutrisi yang diperlukan (Nurul, 2010).

Pada penelitian mengenai timbulnya caries dentis yang dilakukan melalui pemeriksaan caries, menunjukkan bahwa 60 orang responden non perokok dimana tidak mengalami caries dentis sebanyak 22 orang responden $(17,5 \%)$ dan 38 orang responden $(30,2 \%)$ mengalami caries dentis. Sedangkan 18 orang responden yang merupakan perokok ringan dimana tidak mengalami caries dentis sebanyak 10 orang $(7,9 \%)$ dan 8 orang $(6,3 \%)$ mengalami caries dentis. Dari 24 orang responden yang merupakan perokok sedang dimana tidak mengalami caries dentis sebanyak 5 orang $(4,0 \%)$ dan 19 orang $(15,1 \%)$ mengalami caries dentis.

Dari 24 orang responden yang merupakan perokok berat dimana tidak mengalami caries dentis sebanyak 2 orang $(1,6 \%)$ dan 22 orang $(17,5 \%)$ mengalami caries dentis. Hasil pengujian dengan uji korelasi Rank Spearman menunjukkan bahwa antara kebiasaan merokok dan timbulnya caries dentis pada siswa SMK Muhammadiyah 1 Kota Malang mempunyai hubungan yang signifikan (bermakna) dengan nilai signifikansi $(\mathrm{p}=0.003)<0.05$, dengan koefisien korelasi sebesar 0.266 yang bernilai positif. Hal tersebut menunjukkan bahwa semakin berat tingkat kebiasaan merokok siswa SMK Muhammadiyah 1 Kota Malang, maka hal itu akan meningkatkan risiko terjadinya caries dentis.

Dari hasil tabulasi silang menunjukkan bahwa terdapat perbedaan pada status caries antara non perokok, perokok ringan, sedang, dan berat. Pada non perokok terdapat frekuensi non caries namun masih lebih banyak frekuensi caries. Pada perokok ringan, frekuensi status non caries lebih banyak, hal ini berbeda pada perokok sedang dan berat dimana frekuensi status caries lebih banyak. Hal ini menunjukkan bahwa caries dentis tidak hanya dipengaruhi oleh kebiasaan merokok. Merokok hanya salah satu faktor risiko untuk timbulnya caries dentis. Hal ini sesuai dengan penjelasan bahwa caries baru bisa terjadi hanya kalau ada interaksi dari 4 faktor yaitu, faktor host dan gigi, faktor mikroorganisme, faktor waktu, dan faktor substrat (Kidd and Joyston, 1992).

Data lain yang diambil pada penelitian ini adalah frekuensi menggosok gigi, dan lamanya merokok dimana juga mempengaruhi risiko timbulnya caries dentis. Hasil pengujian dengan uji Chi-Square frekuensi menggosok gigi dan timbulnya caries dentis menunjukkan bahwa terdapat hubungan yang signifikan (bermakna) dengan nilai Chi square hitung $=92,735$ sedangkan nilai Chi-square tabel dengan $\mathrm{df}=2$ sebesar 5,991 sehingga dapat diketahui bahwa nilai Chi square hitung $>$ Chi square tabel, disamping itu nilai Signifikansi sebesar 0,000 , dimana nilai $\mathrm{p}<\alpha(\mathrm{p}<0,05)$ sehingga $\mathrm{H}_{0}$ ditolak yang artinya terdapat hubungan yang signifikan antara frekuensi menggosok gigi dan timbulnya caries dentis.

Pada hasil pengujian dengan uji Chi-Square lamanya merokok dan timbulnya caries dentis menunjukkan bahwa terdapat hubungan yang signifikan (bermakna) dengan nilai Chi square hitung $=13,499$ sedangkan nilai Chi-square tabel dengan $\mathrm{df}=3$ sebesar 7,82 sehingga dapat diketahui bahwa nilai Chi square hitung $>$ Chi square tabel, disamping itu nilai Signifikansi sebesar 0,004, dimana nilai $\mathrm{p}<\alpha(\mathrm{p}<$ $0,05)$ sehingga $\mathrm{H} 0$ ditolak yang artinya terdapat hubungan yang signifikan antara lamanya merokok dan timbulnya caries dentis. Dari hasil analisis korelasi menggunakan product moment antara frekuensi menggosok gigi dan jumlah batang rokok sebagai faktor timbulnya caries dentis, menunjukkan bahwa frekuensi menggosok gigi lebih berpengaruh daripada kebiasaan merokok terhadap timbulnya caries dentis dengan nilai signifikansi $(p=0.000)<0.05$, dengan koefisien korelasi sebesar -0.582 yang bernilai negatif. Hal ini menunjukkan bahwa semakin besar frekuensi menggosok gigi maka risiko untuk timbulnya caries dentis semakin rendah.

Dari hasil analisis secara keseluruhan di atas, dapat dikatakan bahwa terdapat hubungan antara kebiasaan merokok dan timbulnya caries dentis, namun merokok bukan merupakan satu-satunya penyebab timbulnya caries dentis, terdapat faktor lain yaitu frekuensi menggososk gigi dan Penelitian ini dilaksanakan tidak terlepas dari keterbatasan yang dimiliki peneliti yaitu penelitian ini tidak mengukur indeks kebersihan mulut atau OHI-S, skor plak dentis, struktur dan susunan gigi, $\mathrm{pH}$ saliva, kadar nikotin rokok, lamanya merokok dan kandungan mikroorganisme dalam gigi, penelitian ini tidak melihat faktor-faktor lain yang mampu menimbulkan caries dentis seperti pola makan.

\section{SIMPULAN}

Berdasarkan hasil penelitian ini maka dapat diambil kesimpulan terdapat hubungan antara kebiasaan merokok dan timbulnya caries dentis pada siswa SMK Muhammadiyah 1 Kota Malang, lebih dari 50\% (52,4\%) siswa SMK Muhammadiyah 1 Kota Malang merupakan perokok aktif dimana dari 66 siswa perokok, 49 siswa diantaranya berstatus caries,dari 126 siswa SMK Muhammadiyah 1 Kota Malang, 39 orang $(31,0 \%)$ berstatus non caries dan 87 orang $(69,0 \%)$ berstatus non caries, terdapat faktor lain yang dapat menimbulkan caries dentis selain merokok yaitu frekuensi menggosok gigi, frekuensi kunjungan ke dokter gigi, dan lamanya merokok.

\section{DAFTAR PUSTAKA}

Depkes R.I.. (2007). 'Pedoman Pengendalian Penyakit Jantung dan Pembulub Darah', Jakarta.

Gondodiputro S. (2007). 'Bahaya Tembakau dan Bentuk Bentuk Sediaan Tembakau', FK UNPAD, Bandung. 
Taylor, Palmer. (2008a). 'Dasar Farmakologi Terapi Volume 1', Penerbit Buku Kedokteran EGC, Jakarta.

Klaassen, Curtis D. (2008b). 'Dasar Farmakologi Terapi Volume 2', Penerbit Buku Kedokteran EGC, Jakarta.

Itjiningsih. (1995). 'Anatomi Gigi', Penerbit Buku Kedokteran EGC, Jakarta.

Johnson, GK. and Slach, NA. (2001). 'Impact of tobacco use on periodontal status', J Dent Educ, vol. 65, no. 4, pp. 313-21.

Kidd E.A.M. and Joyston S. (1992). 'Dasar - Dasar Karies : Penyakit dan Penanggulangannya', Penerbit Buku Kedokteran EGC, Jakarta.

Lie MA. et al. (2001). 'Salivary cystatin activity and cystatin $\mathrm{C}$ in natural and experimental gingivitis in smokers and non-smokers', J Clin Periodontol, 28, pp. 979-984.

Mycek M.J. et al. (2001), Farmakologi Ulasan Bergambar Edisi 2', Widya Medika, Jakarta.

Nurul D.M. (2010). 'Peran Stres Terhadap Kesehatan Jaringan Periodonsium', Penerbit Buku Kedokteran EGC, Jakarta.

Pendersen, G.W. (1996). 'Buku Ajar Praktis Bedah Mulut', Penerbit Buku Kedokteran EGC, Jakarta.

Peraturan Pemerintah Republik Indonesia, Nomor 19 Tahun 2003, 'Pengamanan Rokok Bagi Kesehatan'.

Poppy et al. (1998). 'Kamus Saku Kedokteran Dorland', Penerbit Buku Kedokteran EGC, Jakarta.

Setiawati, A. dan Gan. S. (2007). 'Farmakologi dan Terapi Edisi 5', FK UI, Jakarta.

Sham AS. et al. (2003). 'The effects of tobacco use on oral health', Hong Kong Med J, vol. 9, no. 4, pp. 271-7. 